\section{C'est la guerre?}

- (Compiled in Paris from dispatches: 'Bill to Outlaw Some Uses of English Nears Approval in French Legislature', International Herald Tribune, 6 May 94)

THE NATIONAL Assembly on Thursday approved a bill intended to protect the French language, introducing fines for the public use of English when a French word is available.

The measure, which imposes fines of up to 20,000 francs $(\$ 3,500)$, was backed by the governing coalition of the Union for French Democracy and the Rally for the Republic. Socialist and Communist legislators abstained.

The bill, introduced by Culture Minister Jacques Toubon, now returns to the Senate for a second vote. It is virtually certain of final passage.

In the Assembly debate Wednesday, Didier Mathus, a Socialist, denounced the measure as "unenforceable" and charged that it gave the French language an image of being "narrow and defensive"...

The bill says a dictionary of 3,500 terms and technical expressions published on March 15 will be the bible for France's language police. The dictionary outlaws such English words as airbag, walkman, crash, scoop and software, and provides French equivalents.
- (From Jacques Neher, 'Ad Firms Meet French 101', International Herald Tribune, 29 June 94)

PARIS - Cheeseburgers will have to be renamed in fast-food restaurants around the country under the bill sponsored by Culture Minister Jacques Toubon.

"Hamburger is French, but cheeseburger isn't French and can't be used," said Yves Marek, an adviser to Mr Toubon and author of the bill. "With this law, we're not trying to protect the French language, but rather protect consumers. They should be able to understand what they are buying."

No matter its intent, the law is likely to create more work and boost costs for foreign companies attempting to sell their goods and services in France. Marketers say it would dictate a "French exception" for global or panEuropean ad campaigns tied to English words and expressions.

The only other country where marketers face similar restrictions is Canada, where the French-speaking province of Quebec has also clamped down on commercial use of English. Even though "cheeseburger" survived intact, the company was prompted to replace its Happy Meal with "Joyeux Festin" and Chicken McNuggets with "McCroquettes."

\title{
Unilingual Signs in Quebec and the United Nations Human Rights Committee
}

(From the Annual Report for 1993 of the Commissioner of Official Languages, March 1994, Ottawa)

THE REQUIREMENT of unilingual public signage under Quebec's Charter of the French Language was found to be contrary to the guarantee of freedom of expression in the Canadian Charter of Rights and Freedoms by the Supreme Court of Canada in 1988. In the opinion of the Supreme Court, "... it has not been demonstrated that the prohibition of the use of any language other than French in ss. 58 and 69 of the Charter of the French Language is necessary to the defence and enhancement of the status of the French language in Quebec or that it is proportionate to that legislative purpose." In other words, though such defence and enhancement were valid government objectives, the Court felt that the means chosen to achieve them were disproportionate: "Thus, whereas requiring the predominant display of the French language, even its marked predominance, would be proportional to the goal of promoting and maintaining a French 'visage linguistique' in Quebec and therefore justified under the ... Canadian Charter, requiring the exclusive use of French has not been so justified." 